\title{
ANALYSIS OF FINANCIAL STATEMENTS BASED ON INTERPRETATION OF FINANCIAL ACCOUNTING STANDARDS NO. 35
}

\author{
(Case Study Church I in Tanawangko)
}

\author{
SELVIE. J. NANGOY \\ Department Of Accounting, \\ Polytechnic of Manado Country
}

DOI: $10.31364 / \mathrm{SCIRJ} / \mathrm{v} 8.19 .2020 . P 0920810$

http://dx.doi.org/10.31364/SCIRJ/v8.i9.2020.P0920810

\begin{abstract}
A non-profit entity is an entity whose main objective is to support an issue or public interest, with non-commercial purposes, without any concern for profit-seeking (monetary) matters. In preparing the financial statements of non-profit entities, the Indonesian Institute of Accountants stipulates Interpretation of Financial Accounting Standards No. 35 as the standard governing the financial reporting of non-profit entities. The purpose of this research, to find out the financial statements made by church I, Tanawangko. The research method used in this research is descriptive qualitative. The data used in this study were obtained from sources, namely the Secretary of the Congregation, the Head of the Congregation, and Church Officials. The results showed that the financial statements of the church I, Tanawangko, were not in accordance with the Interpretation of Financial Accounting Standards No. 35. However, in terms of financial accountability, it has presented the church's financial position properly and clearly because it refers to the provisions of the Church's ordinances.
\end{abstract}

Keywords: Non-Profit Entities, Church, Interpretation of Financial Accounting Standards No. 35

\section{INTRODUCTION}

The financial report is something that is very much needed in an entity or company because it will be the benchmark, progress or decline of a company. Financial reports aim to provide financial information which is an account of every company's work. Preparation of financial reports is something that must be done by every company, whether it is a profit-oriented company, where this company is a company that prioritizes profit or profit, or a non-profit company, that is, the type of business is not profit-oriented or profit-oriented.

A non-profit entity is a non-profit company. Where a non-profit entity is an entity that does not prioritize profit. The non-profit entity in carrying out its operational activities, obtains funds from donors voluntarily, and does not expect a return on the funds given. The forms and types of non-profit entities vary, starting from both central and local governments, public facilities, such as hospitals and schools, foundations generally established by private parties, orphanages. Orphanages, such as orphanages, nursing homes, disabled homes, political parties, and religious institutions. Religious institutions are one of the non-profit entities that are often found in the community. Religious institutions in carrying out their operational activities receive charity funds, as well as donations from members of these religious institutions. Where all religious institutions teach their members to love, care for one another and give one another. Thus, for every fund given by the volunteer, there needs to be reporting, as well as accountability by the church institution.

The church is a religious organization, of course there needs to be accountability, for any funds obtained from many members of the congregation, spread over 26 columns, and spread over four villages, who have given without expecting anything in return. The congregation is one of the users of financial reports, of course it needs to be clear about the management and reporting of church finances. Transparency is important so that it can produce accurate financial information and can be used by every user of financial reports. 
Therefore, based on the background of the above writing, the researcher is interested in knowing whether the church I Tanawangko has made financial reports in accordance with the Interpretation of Financial Accounting Standards 35, which includes a Statement of Financial Position, a Comprehensive Statement of Income, a Report on Changes in Net Assets and a Statement of Cash Flow. as well as Notes on Financial Statements, so that it can be accounted for to each user of financial statements.

\section{RESEARCH METHODS}

In this research, researchers used descriptive qualitative methods. The descriptive quantitative approach is expected to be able to produce in-depth descriptions of speech, writing, and observable behavior of a particular individual, group, community, and organization in a certain context, which is studied from a comprehensive, comprehensive, and holistic perspective. Data sources, namely primary data and secondary data. Primary data is the type of data obtained through observation, and direct interviews with sources (the Secretary of the Congregation, the Head of the Congregation and Church Officials), namely in the form of transaction evidence, a list of assets, and the financial statements of Church I, Tanawangko. Meanwhile, secondary data is obtained through various literatures, namely books, journals, writings related to the research in question, in this case, namely literature on Research Methods, Non-Profit Accounting, Financial Statements and so on.

\section{DISCUSSION}

In carrying out its financial activities, Church I, Tanawangko centralizes all transactions, such as offerings, tithes, thanksgiving envelopes, and other income which are centered in church accounts, in order to facilitate the preparation and reporting of finances, and facilitate the process of financial supervision. However, there are several policies by the Congregational Council Worker Body, which give authority to several parties, such as the development committee in compiling and reporting the development committee's financial reports separately, so that the financial activities of the committee will run smoothly and be directed.

\section{Chart 3.1 Financial Management Process At Church I Tanawangko}

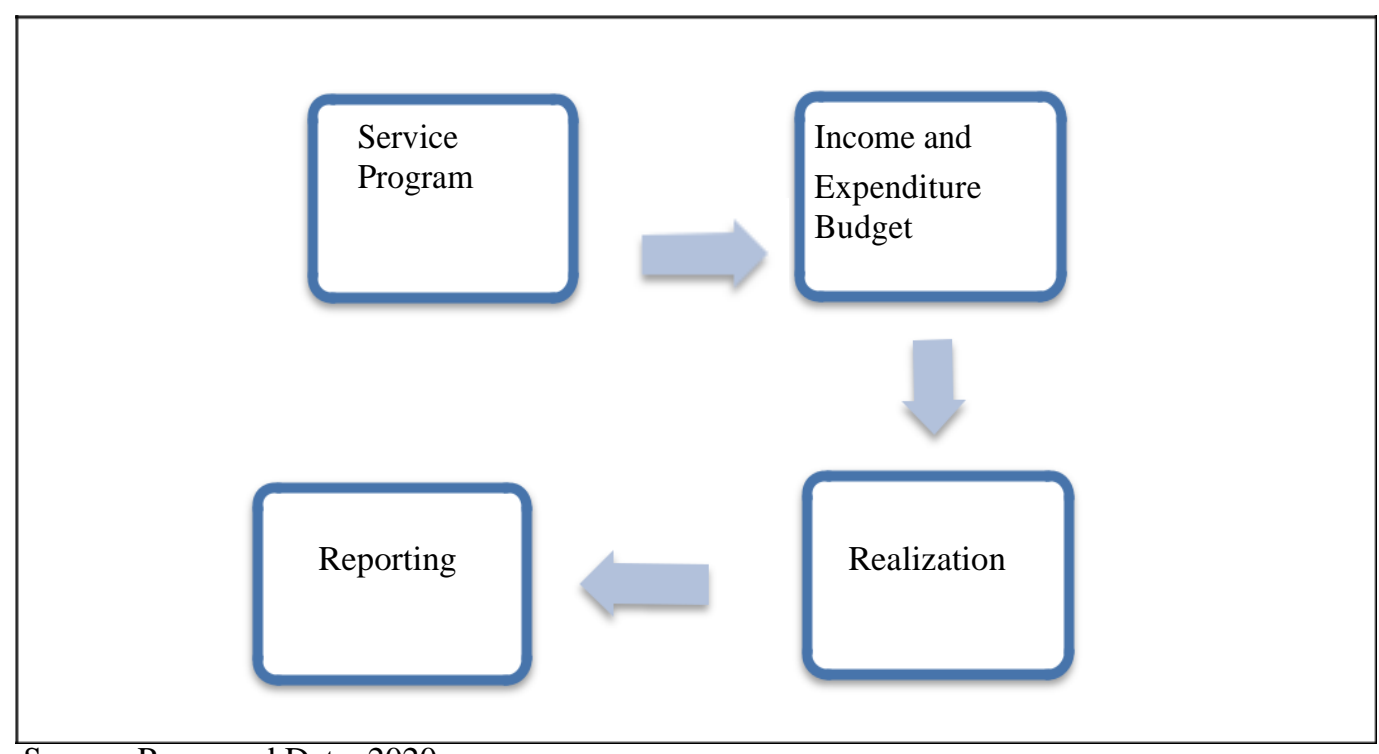

Source: Processed Data, 2020

\subsection{Church Financial Management Process}

\subsubsection{Determination of the Budget and income of the Congregation}

Determination of the Income Budget and Church Expenditures, carried out by the Council of Congregations Worker Body, through the Council of Congregations which was attended by all Structures in church I, Tanawangko. The following is a list of the Income Budget and Shopping church I, Tanawangko:

Table 3.1 Income Budget for the Church I Tanawangko in 2020

\begin{tabular}{|c|l|c|}
\hline NUMBER & \multicolumn{1}{|c|}{ BUDGET } & BUDGET PLAN, 2020 \\
\hline A & ROUTINE WORSHIP OFFERINGS & \\
\hline A.1 & Sunday Service & IDR. XXX \\
\hline A. 2 & Column Worship & IDR. XXX \\
\hline A.3 & BIPRA Worship & IDR. XXX \\
\hline
\end{tabular}




\begin{tabular}{|c|c|c|}
\hline A.4 & Worship Service Commission, and the Elderly & IDR. XXX \\
\hline A.5 & Sunday School Service & IDR. XXX \\
\hline $\mathbf{B}$ & SPECIAL WORSHIP OFFERS & \\
\hline B.1 & New Year 1 & IDR. XXX \\
\hline B.2 & New Year 2 & IDR. XXX \\
\hline B.3 & Good Friday & IDR. XXX \\
\hline B.4 & Easter I and II & IDR. XXX \\
\hline B.5 & Ascension Day & IDR. XXX \\
\hline B.6 & Pentecost Day & IDR. XXX \\
\hline B.7 & PI and PK Anniversary & IDR. XXX \\
\hline B.8 & Republic of Indonesia Anniversary & IDR. XXX \\
\hline B.9 & Church Anniversary Service & IDR. XXX \\
\hline B. 10 & Congregational Anniversary & IDR. XXX \\
\hline & CHRISTMAS EVE & \\
\hline B.11 & Christmas 1 & IDR. XXX \\
\hline B.12 & Christmas 2 & IDR. XXX \\
\hline B.13 & End of year & IDR. XXX \\
\hline B.14 & Holy communion & IDR. XXX \\
\hline B.15 & ETC & IDR. XXX \\
\hline B.16 & $\begin{array}{l}\text { CELEBRATION WELCOMING THE } \\
\text { BIRTH OF JESUS CHRIST }\end{array}$ & \\
\hline B.16.1 & Congregation & IDR. XXX \\
\hline B.16.2 & Column & IDR. XXX \\
\hline B.16.3 & ETC & IDR. XXX \\
\hline B.17 & GRIEF WORSHIP & \\
\hline B.17.1 & The Night of Comfort & IDR. XXX \\
\hline B.17.2 & Funeral & IDR. XXX \\
\hline B.17.3 & ETC & IDR. XXX \\
\hline $\mathrm{C}$ & THANK YOU COVER & \\
\hline C. 1 & New Year's cover & IDR. XXX \\
\hline C.2 & Anniversary cover & IDR. XXX \\
\hline C.3 & ETC & IDR. XXX \\
\hline $\mathrm{D}$ & OTHER INCOME & \\
\hline D.1 & Marriage Administration, Baptist, & IDR. XXX \\
\hline D.2 & ETC & IDR. XXX \\
\hline
\end{tabular}

Source: Church I, Tanawangko

Table 3.2 Church Expenditure Budget for 2020

\begin{tabular}{|c|l|c|}
\hline NUMBER & \multicolumn{1}{|c|}{ BUDGET } & BUDGET PLAN, 2020 \\
\hline A & CENTRALIZATION AND SUBSIDIES & IDR. XXX \\
\hline A.1 & Centralization of the Church & IDR. XXX \\
\hline A.2 & Regional Centralization & IDR. XXX \\
\hline A.3 & Extra Territory & IDR. XXX \\
\hline A.4 & ETC & \\
\hline B & BENEFITS & \\
\hline B.1 & STRUCTURAL & IDR. XXX \\
\hline B.1.1 & Chairman & IDR. XXX \\
\hline B.1.2 & Vice Chairman & IDR. XXX \\
\hline B.1.3 & Secretary & IDR. XXX \\
\hline B.1.4 & Treasurer & IDR. XXX \\
\hline B.1.5 & Member & IDR. XXX \\
\hline B.2 & FUNCTIONAL & IDR. XXX \\
\hline B.2.1 & Chief Pastor & IDR. XXX \\
\hline B. 2.2 & Pastor of the congregation & IDR. XXX \\
\hline B.2.3 & Elder & IDR. XXX \\
\hline B. 2.4 & Shamas & IDR. XXX \\
\hline B.2.5 & Sexton & IDR. XXX \\
\hline B.2.6 & ETC & IDR. XXX \\
\hline C & MEETINGS & IDR. XXX \\
\hline C.1 & Meeting Incentives & \\
\hline C.2 & Meeting Consumption & \\
\hline C.3 & ETC & \\
\hline D & INCENTIVE KADIM & \\
\hline & & \\
\hline
\end{tabular}




\begin{tabular}{|c|l|c|}
\hline D.1 & Synod & IDR. XXX \\
\hline D.2 & Territory & IDR. XXX \\
\hline D.3 3 & ETC & IDR. XXX \\
\hline E & $\begin{array}{l}\text { COST OF OFFICE WRITING TOOLS AND } \\
\text { WORSHIP EQUIPMENT }\end{array}$ & \\
\hline E. 1 & Office Stationery & IDR. XXX \\
\hline E. 2 & ETC & IDR XXX \\
\hline F & DAKONIA & IDR XXX \\
\hline F.1 & Hospital & IDR. XXX \\
\hline F. 2 & Grief & IDR XXX \\
\hline F. 3 & ETC & IDR. XXX \\
\hline G & OTHER COSTS & IDR. XXX \\
\hline G.1 & Special Servant Supplies & IDR XXX \\
\hline G.2 & ETC & \\
\hline & TOTAL & \\
\hline
\end{tabular}

Source: Church I, Tanawangko

\subsubsection{Accountability and Financial Reporting Stage}

In the financial reporting process, church I, Tanawangko. The treasurer keeps records only limited to the general cash book (in-out) manually. Then, it is reported to each party concerned. The following is the financial report prepared by the Church Council Workers Council of the Church I, Tanawangko:

Table 3.3 Financial Statements Of 'Church I' Tanawangko

\begin{tabular}{|c|c|c|c|c|}
\hline DATE & INFORMATION & DEBIT & CREDIT & BALANCE \\
\hline 1 May 2020 & $\begin{array}{l}\text { Balance At The Beginning of } \\
\text { May } 2020\end{array}$ & & & IDR XXX \\
\hline \multirow[t]{21}{*}{3 May 2020} & Sunday Worship Offerings & IDR XXX & & IDR XXX \\
\hline & Extra Collections & IDR XXX & & IDR XXX \\
\hline & $\begin{array}{l}\text { Evangelization Worship } \\
\text { Collection }\end{array}$ & IDR XXX & & IDR XXX \\
\hline & $\begin{array}{l}\text { PERSONAL ANNIVERSARY } \\
\text { THANKSGIVING COVER }\end{array}$ & & & \\
\hline & Anniversary (Researchers join) & IDR XXX & & IDR XXX \\
\hline & $\begin{array}{l}\text { WEDDING THANKSGIVING } \\
\text { COVER }\end{array}$ & & & \\
\hline & Y.S Family & IDR XXX & & IDR XXX \\
\hline & GRADUATE COVER & & & \\
\hline & AT's younger brother & IDR XXX & & IDR XXX \\
\hline & TiTHE COVER & & & \\
\hline & N.Y Family & IDR XXX & & IDR XXX \\
\hline & EASTER COVER & & & \\
\hline & P.J Family & IDR XXX & & IDR XXX \\
\hline & ETC & IDR XXX & & IDR XXX \\
\hline & HOLY MEETING COVER & & & \\
\hline & COLUMN 23 & IDR XXX & & IDR XXX \\
\hline & EXIT & & & \\
\hline & Preacher & & IDR XXX & IDR XXX \\
\hline & LCD & & IDR XXX & IDR XXX \\
\hline & Synod Centralized Deposit & & IDR XXX & IDR XXX \\
\hline & $\begin{array}{l}\text { Treasurer Transport, Depositing } \\
\text { Centralized Money to the Bank }\end{array}$ & & IDR XXX & IDR XXX \\
\hline \multirow[t]{6}{*}{10 Mei 2020} & Sunday Worship Offerings & IDR XXX & & IDR XXX \\
\hline & Extra Collections & IDR XXX & & IDR XXX \\
\hline & $\begin{array}{l}\text { Evangelization Worship } \\
\text { Collection }\end{array}$ & IDR XXX & & IDR XXX \\
\hline & $\begin{array}{l}\text { PERSONAL ANNIVERSARY } \\
\text { THANKSGIVING COVER }\end{array}$ & & & \\
\hline & Anniversary of ML Family & IDR XXX & & IDR XXX \\
\hline & ETC & IDR XXX & & IDR XXX \\
\hline
\end{tabular}

www.scirj.org

(C) 2020, Scientific Research Journal

http://dx.doi.org/10.31364/SCIRJ/v8.i9.2020.P0920810

This publication is licensed under Creative Commons Attribution CC BY. 


\begin{tabular}{|c|c|c|c|c|}
\hline & \begin{tabular}{|l} 
THANKSGIVING COVER \\
WEDDING ANNIVERSARY
\end{tabular} & & & \\
\hline & B.P Family & IDR XXX & & IDR XXX \\
\hline & ETC & IDR XXX & & IDR XXX \\
\hline & $\begin{array}{l}\text { OTHER THANKSGIVING } \\
\text { COVER }\end{array}$ & & & \\
\hline & E.T Family & IDR XXX & & IDR XXX \\
\hline & ETC & IDR XXX & & IDR XXX \\
\hline & TITHE COVER & & & \\
\hline & N.T Family & IDR XXX & & IDR XXX \\
\hline & EASTER COVER & & & \\
\hline & NL Family & IDR XXX & & IDR XXX \\
\hline & ETC & IDR XXX & & IDR XXX \\
\hline & KELUAR & & & \\
\hline & Preacher & & IDR XXX & IDR XXX \\
\hline & LCD & & IDR XXX & IDR XXX \\
\hline & Internet Quota & & IDR XXX & IDR XXX \\
\hline & ETC & & IDR XXX & IDR XXX \\
\hline 11 Mei 2020 & Regional Centralization & & IDR XXX & IDR XXX \\
\hline 13 Mei 2020 & Meeting Consumption & & IDR XXX & IDR XXX \\
\hline & ETC & & IDR XXX & IDR XXX \\
\hline 17 Mei 2020 & Sunday Worship Offerings & IDR XXX & & IDR XXX \\
\hline & Extra Collect & IDR XXX & & IDR XXX \\
\hline & ETC & IDR XXX & & IDR XXX \\
\hline & $\begin{array}{l}\text { PERSONAL ANNIVERSARY } \\
\text { THANKSGIVING COVER }\end{array}$ & & & \\
\hline & NT Annuversary & IDR XXX & & IDR XXX \\
\hline & ML Anniversary & IDR XXX & & IDR XXX \\
\hline & ETC & IDR XXX & & IDR XXX \\
\hline & $\begin{array}{l}\text { OTHER THANKSGIVING } \\
\text { COVER }\end{array}$ & & & \\
\hline & Gratitude IR Family & IDR XXX & & IDR XXX \\
\hline & ETC & IDR XXX & & IDR XXX \\
\hline & EXIT & & & \\
\hline & Preacher & & IDR XXX & IDR XXX \\
\hline & LCD & & IDR XXX & IDR XXX \\
\hline & Photocopy & & IDR XXX & IDR XXX \\
\hline & Church Electricity & & IDR XXX & IDR XXX \\
\hline 18 Mei 2020 & $\begin{array}{l}\text { Diakonia for the Sick } \\
\text { Congregation }\end{array}$ & & IDR XXX & IDR XXX \\
\hline 24 Mei 2020 & Incentive Allowance & & IDR XXX & IDR XXX \\
\hline & Sunday Worship Offerings & IDR XXX & & IDR XXX \\
\hline & Extra Colection & IDR XXX & & IDR XXX \\
\hline & ETC & IDR XXX & & IDR XXX \\
\hline & $\begin{array}{l}\text { PERSONAL ANNIVERSARY } \\
\text { THANKSGIVING COVER }\end{array}$ & & & \\
\hline & D.T Anniversary & IDR XXX & & IDR XXX \\
\hline & ETC & IDR XXX & & IDR XXX \\
\hline & \begin{tabular}{|l|} 
THANKSGIVING COVER \\
WEDDING ANNIVERSARY
\end{tabular} & & & \\
\hline & RM Family & IDR XXX & & IDR XXX \\
\hline & ETC & IDR XXX & & IDR XXX \\
\hline & $\begin{array}{l}\text { OTHER THANKSGIVING } \\
\text { COVER }\end{array}$ & & & \\
\hline & B.T Family & IDR XXX & & IDR XXX \\
\hline & ETC & IDR XXX & & IDR XXX \\
\hline & TITHE COVER & & & \\
\hline & L.L Family & IDR XXX & & IDR XXX \\
\hline
\end{tabular}




\begin{tabular}{|c|c|c|c|c|}
\hline & ETC & IDR XXX & & IDR XXX \\
\hline & $\begin{array}{l}\text { PASTORIES } \\
\text { DEVELOPMENT COVER }\end{array}$ & & & \\
\hline & I.T Family & IDR XXX & & IDR XXX \\
\hline & EASTER COVER & & & \\
\hline & L.R Family & IDR XXX & & IDR XXX \\
\hline & ETC & IDR XXX & & IDR XXX \\
\hline & EXIT & & & \\
\hline & Preacher & & IDR XXX & IDR XXX \\
\hline & LCD & & IDR XXX & IDR XXX \\
\hline & Photocopy, Worship Procedures & & IDR XXX & IDR XXX \\
\hline & ETC & & IDR XXX & IDR XXX \\
\hline 30 Mei 2020 & Diakonia of the Sick, N.Y. & & IDR XXX & IDR XXX \\
\hline & Buy Cake & & IDR XXX & IDR XXX \\
\hline & ETC & & IDR XXX & IDR XXX \\
\hline 31 Mei 2020 & Pentecost Worship Offerings & IDR XXX & & IDR XXX \\
\hline & Extra Colections & IDR XXX & & IDR XXX \\
\hline & ETC & IDR XXX & & IDR XXX \\
\hline & $\begin{array}{l}\text { OTHER WORSHIP } \\
\text { COLLECTES }\end{array}$ & & & \\
\hline & Funeral Services, the late $\mathrm{F}$ & IDR XXX & & IDR XXX \\
\hline & 40 Days of Worship & IDR XXX & & IDR XXX \\
\hline & ETC & & & \\
\hline & $\begin{array}{l}\text { PERSONAL ANNIVERSARY } \\
\text { THANKSGIVING COVER }\end{array}$ & & & \\
\hline & M.S Anniversary & IDR XXX & & IDR XXX \\
\hline & ETC & IDR XXX & & IDR XXX \\
\hline & $\begin{array}{l}\text { SAMPUL SYUKUR HUT } \\
\text { PERKAWINAN }\end{array}$ & & & \\
\hline & R.M Family & IDR XXX & & IDR XXX \\
\hline & ETC & IDR XXX & & IDR XXX \\
\hline & \begin{tabular}{|l} 
THANKSGIVING FOR \\
MARRIAGE Anniversary
\end{tabular} & IDR XXX & & IDR XXX \\
\hline & N.N Family & IDR XXX & & IDR XXX \\
\hline & ETC & IDR XXX & & IDR XXX \\
\hline & TITHE COVER & & & \\
\hline & M.L Family & IDR XXX & & IDR XXX \\
\hline & $\begin{array}{l}\text { Pastors, special ministries, } \\
\text { clerks, sexton and teachers }\end{array}$ & IDR XXX & & IDR XXX \\
\hline & EXIT & & & \\
\hline & Preacher & & IDR XXX & IDR XXX \\
\hline & Diakonia for the N Family is sick & & IDR XXX & IDR XXX \\
\hline & ETC & & IDR XXX & IDR XXX \\
\hline & TOTAL & IDR XXX & IDR XXX & IDR XXX \\
\hline CASH BALAN & CE AT THE END OF APRIL 2020 & IDR XXX & & \\
\hline MAY $2020 \mathrm{REV}$ & ENUE & IDR XXX + & & \\
\hline TOTAL REVEN & JUE & IDR XXX & & \\
\hline SHOPPING MA & Y 2020 & IDR XXX - & & \\
\hline FINAL BALAN & CES MAY 2020 & IDR XXX & & \\
\hline
\end{tabular}

Source: Church I Tanawangko, 2020

\subsection{Presentation of Church Financial Statements}

The Working Body of the Congregational Council is based on the Church Procedures that have been compiled by the Synod Council Working Body, Preparing the Expenditure and Income Budget, as stated in Church Procedures, Part IX Article 5 Paragraph 2 concerning Budget Formulation In the preparation and determination of the Expenditure and Income Budget. The Congregational Council Workers' Board together 
with all Special Servants, which also involves the Congregational Transfer Agency, jointly implement the Assembly Session

Annual Congregation to determine the Expenditure Budget and Income for one year of service, which is valid from 1 January to 31 December of the current year. In the realization stage, the Congregational Council Workers' Board uses the Budget and Stipulation as a guideline in the realization of the Program, including in the realization of the Expenditure Budget and Income that has been previously prepared, in the Congregational Council Session. Then, every time a transaction occurs, the treasurer who has responsibility in the field of finance records every transaction that occurs, both cash receipts and disbursements.

After the realization stage, then enter the Reporting stage, where the Congregation Treasurer will prepare a financial report at the end of each current month based on the records / transactions that have occurred in that month, which then the financial statements will be reviewed by the Congregation's Department of Regional Office every 6 months. The following is the flow of the financial management of church I, Tanawangko:

Chart 3.2 Financial Management of the Church I in Tanawangko

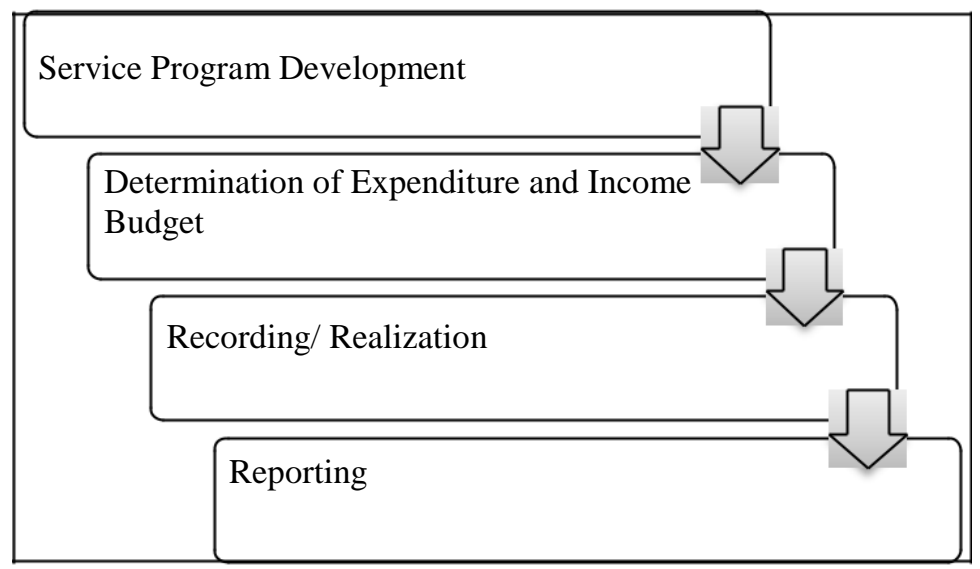

Source: Processed Data, 2020

\subsection{Church Accounting Terminology}

As a basic requirement to be able to learn something science, art, skills, and expertise. First of all, of course you have to understand well the basic terminology that is commonly used in the object of study. Some of the basic church accounting terminologies that need to be understood, and understood in this study, are as follows:

a. Assets are resources obtained from resource providers, namely the congregation, which are the source of economic benefits for the church

b. Liability, is a debt / obligation of the church that occurs as a result of the church not fulfilling a transaction agreement that has been previously agreed.

c. Income, is all types of church income that comes from resource givers, namely the church in the form of money / goods

d. Burdens, are all types of church expenses, namely in terms of meeting the needs of church activities

e. Accounts receivable, is the responsibility of the resource giver (congregation) who has committed to the church to provide resources, as previously agreed, but there is a delay, so that the church recognizes the transaction as Accounts Receivable.

f. Dalam From recording transactions to Financial Reporting, each transaction is grouped into two parts, namely Debits and Credits. A). Debit. In recording financial statements, transactions that add cash are recorded in the Debit column, such as Sunday Service Offerings, Column Worship Offerings, Extra Pundits, Thanksgiving Covers, etc. Conversely, transactions that reduce cash, are recorded in the credit column, such as Church Worker Benefits, Khadim Costs, Electricity Costs, and all transactions that reduce cash.

\section{CONCLUSION}

Based on the results of the discussion, it can be concluded that

1. Church I, Tanawangko in its financial reporting is quite clear, and its financial reports can be accounted for to the congregation. However, it is not in accordance with the Interpretation of Financial Accounting Standards 
No. 35 which is a standard in the preparation of financial statements for non-profit entities, which include: Statements of Financial Position, Comprehensive Income Statements, Statements of Changes in Net Assets and Cash Flow Statements, and Notes to Financial Statements, so that they can be accounted for. on each user of financial statements.

2. The Tanawangko church financial management refers to church procedures that have been established by the Synod Council Working Body

3. Church I, Tanawangko has prepared a report on the realization of the budget, but it is not in accordance with the applicable standards

4. Accounting activities at the Tanawangko church are limited to recording cash in and cash out, which has not fully referred to the Interpretation of Financial Accounting Standards No. 35, which compiles five financial reports, consisting of statements of financial position, comprehensive income statements, reports of changes in net assets, cash change reports and notes to financial statements.

\section{REFERENCES}

Government regulations. 2010. "Government Accounting Standards Statement No. 02 Regarding the Budget Realization Report "Jakarta: Government Accounting Standards Committee

Gultom, I.R,. dan Poputra, A.T. 2015. Analysis of the Implementation of Statement of Financial Accounting Standards No. 45, Concerning Non-Profit Organization Financial Statements, In Achieving Transparency and Accountability of the GMIM Synod Office. EMBA Journal, 3, 527537

Hasunah. 2015. "Preparation of Financial Statements, Islamic Education Foundation According to Statement of Financial Accounting Standards 45 (Case Study at YPIs Raudlatut Thalabah in Kediri Regency). Essay. Accounting major. Faculty of Economics. University of Jember

Ikatan Akuntan Indonesia (IAI), 2018. "Statement of Financial Accounting Standards", Jakarta, Financial Accounting Standards Board

Ikatan Akuntan Indonesia (IAI), 2018. “Interpretation of Financial Accounting Standards”, Jakarta, Financial Accounting Standards Board

Ikatan Akuntan Indonesia (IAI), 2009. "Financial Accounting Standards for Entities without Public Accountability”, Jakarta: Financial Accounting Standards Board.

Kartika, Hans dkk. 2016. "Financial Accounting Based on IFRS Based SAK". Jakarta: Indonesian Accountants Association

Manurung, Elvy, M. 2011. “Basic Accounting (For Beginners)” Jakarta : Erlangga

Ratmono, Dwi dan Sholihin, Mahfud. 2015. "'Accrual-Based Regional Financial Accountingl” Yogyakarta : UPP STIM YKPN

Sadeli, Lili, M. 2011. “Accounting Basics” Jakarta : Bumi Askara

Working Body of the Evangelical Christian Church Synod Council in Minahasa, 2016. "GMIM Church Administration” Tomohon: GMIM Synod Council Working Body 